\title{
Macrophage/Monocyte Receptor for Nonenzymatically Glycosylated Proteins Is Upregulated by Cachectin/Tumor Necrosis Factor
}

Helen Vlassara, Lyle Moldawer, and Betty Chan

Laboratory of Medical Biochemistry, The Rockefeller University, New York 10021

\begin{abstract}
Proteins of extracellular matrix undergo over time multiple reactions with glucose to form advanced glycosylation endproducts (AGEs) which are highly active in protein crosslinking, and have been implicated in tissue damage associated with aging and diabetes. A macrophage/monocyte receptor for AGE moieties mediates the uptake of AGE-modified proteins by a process that also induces cachectin/tumor necrosis factor (TNF) and IL-1 secretion. Reasoning that cytokines might regulate this AGE-receptor system, we have evaluated the effect of cachectin/TNF, IL-1, and IFN- $\gamma$ on AGE-protein processing. We report that cachectin/TNF induced a severalfold enhancement of binding, endocytosis, and degradation of AGE-BSA by both murine peritoneal macrophages and human blood monocytes in vitro, and that cachectin/TNF enhanced the rate of disappearance of AGE-modified red blood cells in vivo. IL-1 and IFN- $\gamma$ alone did not increase AGE processing, but IFN- $\gamma$ consistently enhanced cachectin/TNF-induced changes in AGE-receptor kinetics. Similar effects were induced by AGE-BSA and FFI-BSA, a chemically synthesized AGE, when used as macrophage stimulants, possibly via cachectin/TNF induction. All upregulatory responses were blocked by anticachectin/TNF monoclonal antibody. These data suggest that AGE-induced cachectin/TNF, in addition to influencing tissue regeneration and remodelling, may also normally regulate the disposal of tissue damaging AGE-proteins through an autocrine upregulation.
\end{abstract}

\section{Introduction}

Glucose can react nonenzymatically with proteins to form, over time, stable covalent adducts called advanced glycosylation endproducts (AGEs), ${ }^{1}$ which are characteristically fluorescent, yellow-brown pigments that can cross-link proteins and nucleic acids (1-3). Accumulation of AGEs on long-lived proteins in vivo has been found to increase linearly with age and is accelerated in patients with diabetes $(1,4)$.

Address reprint requests to Dr. Vlassara, Laboratory of Medical Biochemistry, Box 277, The Rockefeller University, 1230 York Avenue, New York, NY 10021.

Received for publication 30 January 1989 and in revised form 4 August 1989.

1. Abbreviations used in this paper: AGE, advanced glycosylation endproducts; FFI, 2-(2-furoyl)-4-(5)-(2-furanyl)- $1 \mathrm{H}$-imidazole; HA, hexanoic acid; LPS, lipopolysaccharide; rh, recombinant human; TNF, tumor necrosis factor.

J. Clin. Invest.

(C) The American Society for Clinical Investigation, Inc.

0021-9738/89/12/1813/08 $\$ 2.00$

Volume 84, December 1989, 1813-1820
We have previously demonstrated that macrophages possess a high affinity receptor that selectively recognizes proteins modified by AGEs (5). AGE-modified proteins bind to macrophage receptors, become internalized, and are then degraded, with subsequent release of their component amino acids $(5,6)$. Scatchard analysis of AGE-BSA (bovine serum albumin, nonenzymatically glycosylated in vitro) binding to mouse peritoneal macrophages reveals $\sim 1 \times 10^{5}$ binding sites per cell with an affinity constant $\left(K_{\mathrm{a}}\right)$ of $1.75 \times 10^{7} \mathrm{M}^{-1}(6)$, functionally defining the AGE-receptor. A $90-\mathrm{kD}$ protein, with AGE-binding affinity similar to the AGE-receptor has been purified to homogeneity from the cell membranes of the murine macrophage cell line RAW 264.7 (Radoff, S., and H. Vlassara. Submitted for publication.) (7). In addition to taking up AGEmodified proteins, macrophages can recognize intact cells that have AGE chemically attached to their outer membrane, and AGE-modified RBC are removed from the circulation more rapidly than control cells (8). Such studies suggest that accumulation of AGEs on the surface of long-lived cells could be responsible in part for the normal turnover of erythrocytes and endothelial cells, among others.

Binding of AGE-modified proteins to macrophages was recently found to stimulate synthesis and release of two potent monokines, cachectin/TNF and IL-1 (9). The release of these factors with known growth-promoting activity may represent a mechanism by which macrophages signal to nearby cells to remove and replace senescent proteins.

Several macrophage receptors are known to be modulated by hormones and other physiological mediators $(10,11)$, therefore we have been testing for factors that participate in the regulation of $A G E$ receptors. For example, previous studies have revealed that the number and affinity of AGE-receptors on macrophages are inversely correlated in vivo with insulin levels (12), suggesting a regulatory role for insulin in this system. In the present communication we have evaluated the effects of various cytokines including IL-1, cachectin/TNF, and IFN- $\gamma$ on the expression and activity of AGE-receptors in murine and human macrophage/monocytes. These studies support the hypothesis that cachectin/TNF up-regulates AGE receptors on macrophages in vitro and in vivo, apparently via an autocrine regulatory mechanism.

\section{Methods}

Cell preparation. Resident peritoneal macrophages were harvested from mice (Balb/cJ; Jackson Laboratory, Bar Harbor, ME) in PBS as described previously $(5,6)$. After total and differential cell counts, aliquots of $2 \times 10^{6}$ cells were seeded into 24-well culture dishes (Linbro, McLean, VA) and incubated at $37^{\circ} \mathrm{C}$ in $5 \% \mathrm{CO}_{2}$ for $2 \mathrm{~h}$, after which nonadherent cells were removed by rinsing with serum-free medium.

The buffy coat from $100 \mathrm{ml}$ fresh human blood was diluted twofold with saline, $\mathrm{pH} 7.4$, containing $1 \mathrm{mM}$ EDTA. Mononuclear cells were first isolated by centrifugation over Ficoll-Hypaque gradients (8), and were further purified by the Percoll gradient (13). Greater than $99 \%$ of 
the adhering cells were monocytes, as assessed by their ability to spread on surfaces (14) and ingest IgG-coated erythrocytes (15). When ready for use, aliquots of $10^{6}$ monocytes were suspended in RPMI 1640 (Gibco Laboratories, Grand Island, NY), plated into sterile Petri dishes, and incubated for $2 \mathrm{~h}$ at $37^{\circ} \mathrm{C}$ in $5 \% \mathrm{CO}_{2}$. Approximately 1.0 $\times 10^{6}$ cells/well adhered routinely.

Preparation of AGE-modified proteins and AGE-BSA binding assays. AGE-BSA was prepared by incubating bovine serum albumin (BSA; Fraction V; Boehringer-Mannheim Biochemicals, Indianapolis, IN) in $10 \mathrm{mM}$ PBS buffer, pH 7.4 with $50 \mathrm{mM}$ glucose or glucose-6phosphate at $37^{\circ} \mathrm{C}$ for $6 \mathrm{wk}$, as described (6). The amount of AGE formed on all BSA preparations was assessed by characteristic absorption and fluorescence spectra (16) and quantitated by radioimmunoassay (17). FFI-BSA conjugate, a chemically synthesized AGE shown to be recognized by the AGE receptor (6) was made as previously described in detail (18).

Binding studies of AGE-BSA were carried out under optimal conditions for each mediator or stimulant under study (see below), using either murine peritoneal macrophages or human blood monocytes, as described $(6,12)$. AGE-BSA was radioiodinated with carrier-free ${ }^{125} I$ (New England Nuclear Corp., Boston, MA) by the Iodogen method of Fraker and Speck (19) to a specific activity of $\sim 850 \mathrm{cpm} / \mathrm{ng}$ of protein. The amount of radiolabeled material specifically bound was subsequently determined and analyzed by Scatchard analysis (20). Nonspecific binding was generally $<20 \%$ in these experiments. The intracellular accumulation and degradation of AGE-BSA were also measured as described previously (6).

Cachectin/TNF binding assays. Recombinant human cachectin/ TNF (rhTNF; Chiron Corp., Emeryville, CA) was purified to $>99 \%$ electrophoretic homogeneity and radioiodinated by the Iodogen method (19). $10 \mu \mathrm{g}$ of the purified protein was mixed with $5 \mathrm{mCi}$ carrier-free ${ }^{125} \mathrm{I}$ (New England Nuclear) in $75 \mu \mathrm{l}$ of $50 \mathrm{mM}$ Hepes buffer, $\mathrm{pH} 7.8$, in an Iodogen-coated glass tube (Pierce Chemical Co., Rockford, IL) for $20 \mathrm{~min}$ at $4^{\circ} \mathrm{C}$. The reactants were diluted to $2.5 \mathrm{ml}$ with Hepes buffer containing $0.1 \% \mathrm{BSA}$ and $0.5 \mathrm{M}$ sodium iodide and passed through a Sephadex G-25 column (Pharmacia Fine Chemicals, Piscataway, NJ) equilibrated with $50 \mathrm{mM}$ Hepes and $0.1 \% \mathrm{BSA}$. The labeled rhTNF which eluted in the void volume was dialyzed nine times against 1 liter $50 \mathrm{mM}$ Hepes buffer, $\mathrm{pH} 7.8$, containing $0.01 \%$ sodium azide. The specific activity of the ${ }^{125} \mathrm{I}-\mathrm{rhTNF}$ ranged from 6-9 $\times 10^{9} \mathrm{cpm} / \mathrm{mg}$ protein; $>98 \%$ of the radioactivity was protein bound.

Thioglycolate-elicited macrophages from Balb/cJ mice and fresh normal human monocytes were prepared as described $(6,8,13)$, plated in $2 \mathrm{ml}$ RPMI 1640 with $25 \%$ FBS and $0.1 \%$ gentamicin in similar 6-well plates $\left(8 \times 10^{6}\right.$ cells/well $)$ and allowed to adhere for $2 \mathrm{~h}$.

Adherent monolayers were then rinsed three times with cold media containing $10 \% \mathrm{FBS}$ and kept at $4^{\circ} \mathrm{C}$ for another $30 \mathrm{~min}$ when ${ }^{125} \mathrm{I}$ rhTNF was added at different concentrations in the presence or absence of 100 -fold excess unlabeled rhTNF to $1.0 \mathrm{ml}$ of media with serum. Cells were shaken gently for $3 \mathrm{~h}$ at $4^{\circ} \mathrm{C}$. The radioligand-containing medium was subsequently aspirated, and the cells were rinsed three times with $2.0 \mathrm{ml}$ of fresh medium and then three times with 2.0 $\mathrm{ml}$ of PBS. The monolayers were lysed in $1.0 \mathrm{ml}$ of a solution containing $0.1 \%$ sodium deoxycholate and $0.05 \mathrm{~N}$ sodium hydroxide and counted in a gamma counter. The amount of protein in each well was measured by the method of Bradford (21). Wells containing murine macrophages showed no significant variation in cell protein/well, and results were expressed as counts per minute per well. However, wells containing human monocytes showed greater well-to-well fluctuation $(\sim 20 \%)$ due to variable cell loss during washing, therefore results were adjusted for amount of cell protein per well.

Preincubation of mouse macrophages and human monocytes with cachectin/TNF (rhTNF), AGE-, and FFI-BSA. All materials and media used were prepared under endotoxin-free conditions, and passed over an affinity PAK column (Detoxigel; Pierce Chemical Co.). All solutions were assessed for the presence of contaminating endotoxin by a standard Limulus amebocyte lysate assay (Sigma Chemical Co., St. Louis, MO) and found to be negative. In some experiments polymyxin $(100 \mathrm{ng}-10 \mu \mathrm{g} / \mathrm{ml})$ was added to determine whether any of the responses reflected the presence of trace amounts of endotoxin not detectable by the Limulus assay. Cells were preincubated with various concentrations of rhTNF for periods of time between $2 \mathrm{~h}$ and $5 \mathrm{~d}$, after which binding studies of radiolabeled AGE-BSA were performed to define the optimal preincubation conditions for maximal AGE-receptor expression. In some experiments, human monocytes were preincubated in media with $10 \%$ serum alone for $5 \mathrm{~d}$, followed by $48 \mathrm{~h}$ of preincubation with rhTNF, when labeled ligand binding and degradation was tested. In addition, several 48-h preincubations were conducted in the presence of medium with $10 \%$ serum, rhTNF, and recombinant human IFN- $\gamma(1 \mathrm{ng} / \mathrm{ml}, 50 \mathrm{U} / \mathrm{ml}$ ) (Amgen Biologicals, Thousand Oaks, CA).

AGE-BSA or FFI-BSA was added to the isolated macrophages or monocytes at different concentrations (Table II), for $48 \mathrm{~h}$ at $37^{\circ} \mathrm{C}$. Unmodified BSA that had been incubated in PBS alone for 6 wk was used as negative control. Cell monolayers were then washed three times with serum containing medium, after which binding for $2 \mathrm{~h}$ at $4^{\circ} \mathrm{C}$, or uptake and degradation studies for $4 \mathrm{~h}$ at $37^{\circ} \mathrm{C}$ were carried out as described (6). Lipopolysaccharide W. Escherichia coli type (LPS, 0.2 ng/ml; Difco Laboratories, Chagrin Falls, MI), recombinant human IL-1 $\alpha$ (up to $150 \mathrm{ng} / \mathrm{ml}$; a generous gift from Dr. Lomedico; Hoffmann-La Roche, Nutley, NJ), and human IFN- $\gamma(1 \mathrm{ng} / \mathrm{ml}, 50 \mathrm{U} / \mathrm{ml})$ were used in independent experiments as indicated. Finally, a purified monoclonal antibody to recombinant human cachectin/TNF (SDW18.1.1, from a subclone of American Type Culture Collection cell line HB9228) (22) was used in selected experiments. This antibody is shown to completely neutralize TNF biological activity in an L929 cell cytotoxicity assay (22), and does not cross-react with TNF- $\beta$ (lymphotoxin) (unpublished data).

Preparation of rat red blood cells coupled with FFI. Female Wistar rats (200-250 g) were equilibrated in the Rockefeller University Laboratory Animal Research Center for $5 \mathrm{~d}$ before the study. Two animals were anesthetized (pentobarbital $25 \mathrm{mg} / \mathrm{kg}$ i.p.) and exsanguinated, yielding $\sim 5.0 \mathrm{ml}$ of blood. The red cells were washed with $10 \mathrm{vol}$ $\mathrm{Ca}^{+2}$ - and $\mathrm{Mg}^{+2}$-free PBS and coupled with FFI-HA by $10 \mathrm{mM}$ watersoluble carbodiimide as described in detail previously (8). RBC incubated in PBS alone were used as normal controls. A previous study had shown that the half-life of RBC incubated in PBS and carbodiimide was identical to that of normal cells (8). All cell suspensions were subsequently labeled with ${ }^{51} \mathrm{Cr}$ by adding $0.2 \mathrm{mCi} \mathrm{Na}_{2}\left[{ }^{51} \mathrm{Cr}\right] \mathrm{O}_{4}(\mathrm{New}$ England Nuclear) to $5 \mathrm{ml}$ of $50 \%$ packed RBC in RPMI 1640 medium for $1 \mathrm{~h}$ at $37^{\circ} \mathrm{C}$. The labeled erythrocytes were washed with PBS at least four times to remove unbound isotope.

Assessment of red cell survival. On day 0 of the study period, Wistar rats were injected intravenously with $\sim 8 \times 10^{5} \mathrm{cpm}$ of ${ }^{51} \mathrm{Cr}$-labeled normal RBC or FFI-RBC $(200 \mu \mathrm{l})$. The animals were then divided into groups of eight to receive either twice daily injections ( $200 \mu$ li.p.) of either purified recombinant human cachectin/TNF $\alpha$ or normal saline. The quantity of cachectin/TNF $\alpha$ was initially $500 \mu \mathrm{g} / \mathrm{kg} \mathrm{BW}$ per d, but it was raised to $1 \mathrm{mg} / \mathrm{kg}$ per d on day 3 and $1.5 \mathrm{mg} / \mathrm{kg}$ per d on day 5 in order to compensate for the previously described tolerance (23). At the indicated times, the animals were bled $(100 \mu \mathrm{l})$ and the amount of radioactivity was determined.

Statistics. All data are expressed as means \pm SEM and were analyzed with one-way analysis of variance (24).

\section{Results}

The binding, accumulation, and degradation of AGE-BSA by mouse macrophages that had been preincubated with cachectin/TNF, IL- 1 and IFN- $\gamma$ were assessed as described in Methods. As displayed in Fig. 1 the incubation of mouse macrophages with cachectin/TNF $(20 \mathrm{ng} / \mathrm{ml}, 1 \mathrm{nM})$ for a 48-h period resulted in significant increases in the binding, accumulation, and degradation of AGE-BSA. A twofold increase in labeled AGE-BSA specifically bound to macrophages preincu- 


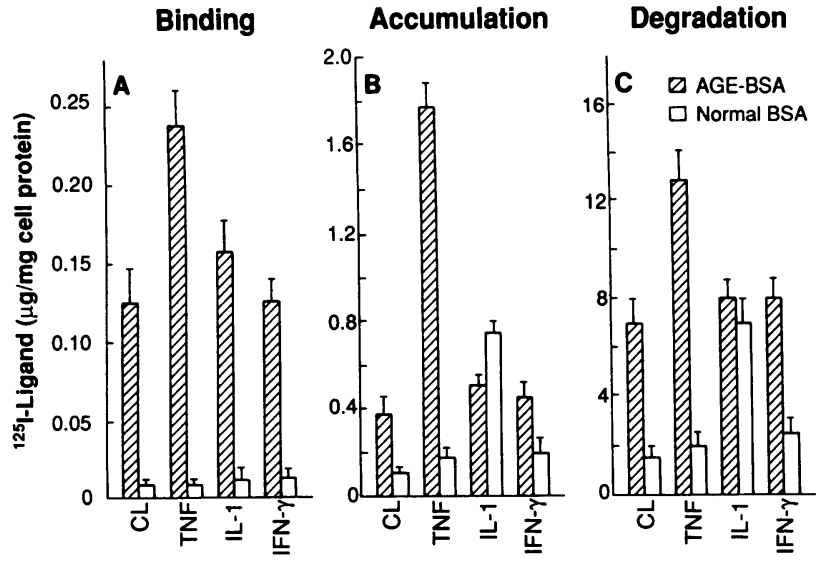

Figure 1. Maximal specific binding $(A)$, intracellular accumulation $(B)$, and degradation $(C)$ of either ${ }^{125} \mathrm{I}$-AGE-modified BSA (25 $\mu \mathrm{g} / \mathrm{ml})$ [ $\mathrm{g}$ ] or ${ }^{125} \mathrm{I}$-normal BSA $(25 \mu \mathrm{g} / \mathrm{ml})$ [] by murine peritoneal resident macrophages after preincubation with the indicated agents for $48 \mathrm{~h}$ at $37^{\circ} \mathrm{C}$. Control wells contained cells preincubated in medium with serum alone, for the same period of time before receiving the appropriate radioactive ligand. Data are expressed as the means \pm SEM of four independent experiments each done in triplicate.

bated with rhTNF was observed as compared with control cells $(P<0.005)$ (Fig. $1 A)$, accompanied by a fourfold increase in the amount accumulated intracellularly after incubation for 4 $\mathrm{h}$ at $37^{\circ} \mathrm{C}(P<0.01)$ (Fig. $\left.1 \mathrm{~B}\right)$, and a twofold increase in the amount degraded by the cells preincubated with rhTNF $(P$ $<0.005)$, measured as TCA soluble radioactivity in the medium (Fig. $1 C$ ); no significant change was observed in the binding and degradation of normal BSA. Under the same conditions, however, there was no significant effect of IL-1 or IFN- $\gamma$ on the binding, accumulation, or degradation of labeled AGE-BSA; although there was a considerable effect on the intracellular accumulation, and degradation of normal BSA by IL-1-treated macrophages, presumably via nonreceptor mediated pathways (Fig. 1). Murine IFN- $\gamma$ added during the preincubation period either alone (Fig. 1) or in combination with cachectin/TNF (not shown) did not produce any remarkable effects on the binding, accumulation, or degradation of either ligand. No significant effects were observed at either higher or lower concentrations of IL-1 or IFN- $\gamma$ (data not shown). The amount of cachectin/TNF found to optimally induce the effect was $20 \mathrm{ng} / \mathrm{ml}(1 \mathrm{nM})$; neither $0.1 \mathrm{nM}$ nor 10 nM rhTNF had a statistically significant effect (Fig. 2). When normal BSA was used as a ligand, only IL-1 elicited an increase

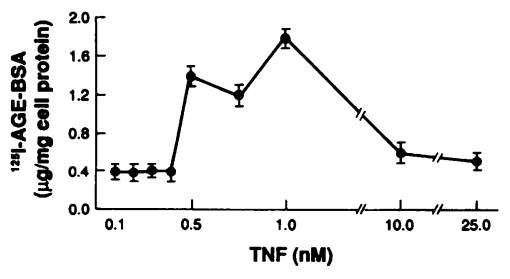

Figure 2. Effect of cachectin/TNF concentration on AGE-receptormediated intracellular accumulation of ${ }^{125} \mathrm{I}$ AGE-BSA by murine resident peritoneal macrophages. Cells were incubated with different concentrations of cachectin/TNF for $48 \mathrm{~h}$, at $37^{\circ} \mathrm{C}$. After washing away cachectin/TNF with serum containing media three times, media with $10 \%$ FCS was replaced and cellular uptake of labeled AGE-BSA for $4 \mathrm{~h}$ at $37^{\circ} \mathrm{C}$ was determined as described (6). Data are expressed as the means \pm SEM of two independent experiments, each performed in triplicate. Amount of radiolabeled AGE-BSA added to the medium was $25 \mu \mathrm{g} / \mathrm{ml}$. in the amount accumulated and degraded compared to control cells (Fig. 1).

The time course of cachectin/TNF-mediated stimulation of radiolabeled AGE-BSA or normal BSA intracellular accumulation, representing the amount of radioactive ligand bound and taken-up minus the amount externalized after proteolytic digestion by murine macrophages is shown in Fig. 3. After a 36-h preincubation with cachectin/TNF a significant increase in the amount of AGE-BSA taken up by the cells was noted that peaked after $48 \mathrm{~h}$ and decreased to initial values by $5 \mathrm{~d}$. Accumulation of normal BSA was never affected by cachectin/TNF pretreatment, and macrophages not preincubated with cachectin/TNF only slightly increased their accumulation of intracellular AGE-BSA.

To assess whether cachectin/TNF treatment had similar effects on AGE processing by human peripheral monocytes, binding studies of ${ }^{125} \mathrm{I}$-AGE-BSA were performed on human monocytes, after a 48-h preincubation in media with or without rhTNF. In the absence of rhTNF, ${ }^{125} \mathrm{I}$-AGE-BSA binding at $4{ }^{\circ} \mathrm{C}$ followed typical saturation kinetics as a function of ligand concentration (Fig. 4, closed circles). Scatchard analysis of the binding data revealed a single class of binding sites numbering $1.40 \pm 0.22 \times 10^{5}$ per cell with an apparent binding affinity $\left(K_{\mathrm{a}}\right)$ of $1.70 \pm 0.2 \times 10^{6} \mathrm{M}^{-1}$ (Fig. 4 , lower inset). However, when freshly isolated human monocytes were preincubated with rhTNF for $48 \mathrm{~h}$, saturated binding of ${ }^{125} \mathrm{I}$-AGE-BSA increased, reaching a maximum level more than twice as great as that reached in the absence of $\operatorname{rhTNF}(P<0.005)$ (Fig. 4, open circles). Scatchard plot analysis indicated a two- to threefold increase in both receptor number and binding affinity $\left(K_{\mathrm{a}}\right)$ compared to untreated cells $(P<0.01)$ (Fig. 4, upper inset, and Table I). In parallel experiments, human monocytes were kept in culture for $5 \mathrm{~d}$, given fresh medium with or without rhTNF, and cultured for an additional $2 \mathrm{~d}$. Binding of labeled AGEBSA to 7-d-old monocytes not exposed to rhTNF, and Scat-

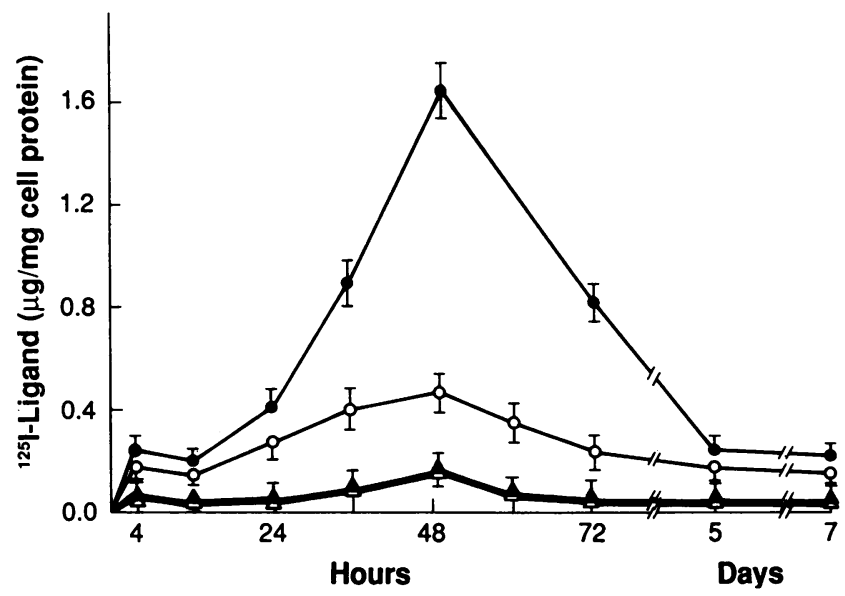

Figure 3. Effect of time in culture on AGE-receptor intracellular accumulation of ${ }^{125} \mathrm{I}-\mathrm{AGE}-\mathrm{BSA}$ by murine resident peritoneal macrophages, after incubation in the presence $(\bullet)$ or absence $(0)$ of cachectin/TNF ( $1 \mathrm{nM})$ added once, at time 0 . After incubation of cells with cachectin/TNF for the indicated periods of time, the monokine was removed by three washings, and the media were replaced. Accumulation of ${ }^{125}$ I-normal BSA by macrophages after preincubation with cachectin/TNF $(\Delta)$ or medium alone $(\Delta)$ is also shown (superimposed symbols). Data are expressed as the means \pm SEM of three independent experiments each done in triplicate. Amount of radioligand added to the medium was $25 \mu \mathrm{g} / \mathrm{ml}$. 


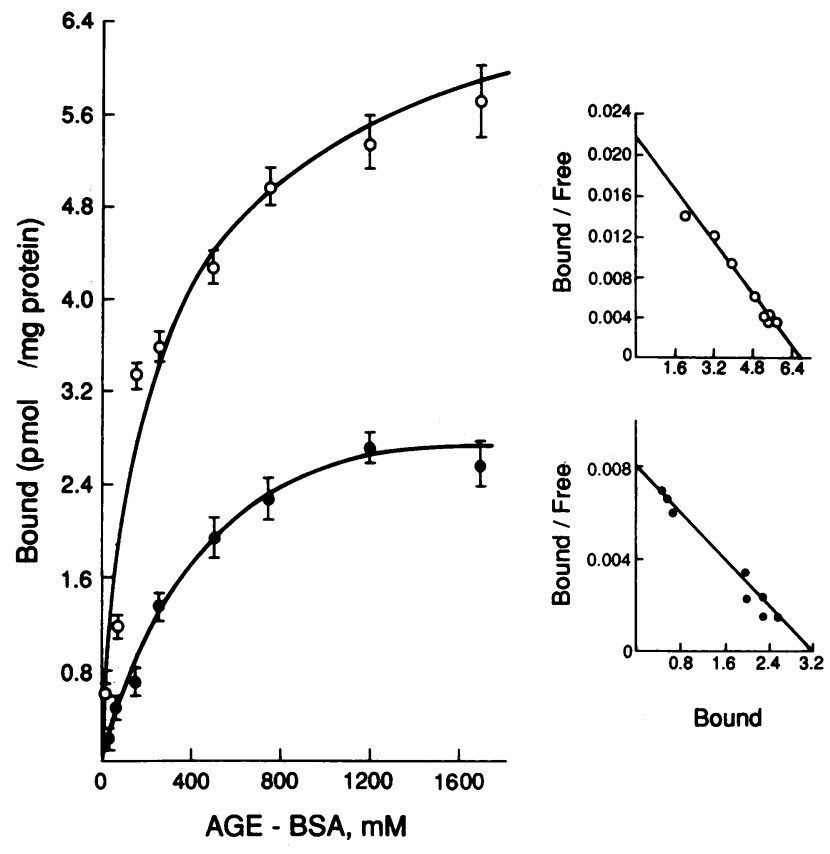

Figure 4. Specific binding of ${ }^{125}$ I-AGE-BSA by freshly isolated human blood monocytes, and Scatchard plot analysis (insets) of data, in the presence or absence of 100 -fold excess unlabeled AGEBSA, after a 48-h preincubation with cachectin/TNF (1 nM) (0) or medium with serum alone (๑). Specific binding data were determined from duplicate values and are expressed as means \pm SEM of three independent experiments. Units for Scatchard analysis are: bound, $\mathrm{pmol} \cdot \mathrm{mg}^{-1}$ cell protein; bound $/$ free, $\mathrm{pmol} \cdot \mathrm{mg}^{-1} \cdot \mathrm{nM}^{-1}$.

chard plot analysis of these data indicated fivefold increase in receptor number, and twofold in binding affinity compared to freshly isolated monocytes $(P<0.01)$. (Table I), but almost 10-fold greater than freshly isolated cells. By contrast, preincubation of 1-wk-old monocytes with rhTNF led to doubling of binding sites $(P<0.005)$, compared to untreated 7 -d-old monocytes (Table I). A significant increase in binding affinity was also noted $(P<0.05)$, even though less pronounced.

Table I. Effect of Time in Culture, and Cachectin/TNF Pretreatment on Human Peripheral Monocyte AGE-receptor Number* $(R)$ and Binding Affinity* $\left(K_{a}\right)$ of ${ }^{125} I-A G E-B S A^{\ddagger}$

\begin{tabular}{|c|c|c|c|c|c|}
\hline $\begin{array}{l}\text { Time in } \\
\text { culture }\end{array}$ & $\begin{array}{c}\text { Cachectin/TNF } \\
\text { pretreatment }\end{array}$ & $R\left(\times 10^{5}\right)$ & $(P)$ & $\begin{array}{c}K_{\mathbf{2}} \\
\left(\times 10^{6} \mathbf{M}^{-1}\right)\end{array}$ & $(P)$ \\
\hline & $\ln M$ & & & & \\
\hline $24 \mathrm{~h}$ & (No) & $0.48 \pm 0.02$ & \multirow{3}{*}{$<0.01$} & $1.7 \pm 0.3$ & \multirow{3}{*}{$<0.0$} \\
\hline $48 \mathrm{~h}$ & (No) & $1.40 \pm 0.22$ & & $1.7 \pm 0.2$ & \\
\hline $48 \mathrm{~h}$ & (Yes) & $3.30 \pm 0.54$ & & $4.5 \pm 0.3$ & \\
\hline $7 \mathrm{~d}$ & (No) & $2.20 \pm 0.52$ & \multirow{2}{*}{$<0.005$} & $3.9 \pm 0.5\}$ & \multirow{2}{*}{$<0.0$} \\
\hline $7 \mathrm{~d}^{\ddagger}$ & (Yes) & $4.90 \pm 0.68\}$ & & $5.4 \pm 0.3\}$ & \\
\hline
\end{tabular}

* Cells were incubated with cachectin/TNF for the indicated periods of time, except in the case of 7-d experiments when cachectin/TNF was added during the last $48 \mathrm{~h}$ in culture. After cachectin/TNF was washed away and replaced by cold media, binding studies of labeled AGE-BSA were performed. Binding sites and affinity were determined by Scatchard plot analysis (20).

${ }^{\ddagger}$ Data are expressed as means \pm SEM of duplicate values from three independent experiments.

$\S$ Cachectin/TNF was added during the last $48 \mathrm{~h}$ in culture.
Intracellular accumulation of ${ }^{125}$ I-AGE-BSA also increased significantly in similar experiments during which freshly prepared human blood monocytes were preincubated with rhTNF in medium containing human $\gamma$-IFN $(1 \mathrm{ng} / \mathrm{ml})$ added as a priming factor $(25,26)$ (Fig. 5). Although these experiments were carried out in the presence of IFN- $\gamma$, this agent alone did not enhance AGE-receptor activity (Fig. 5), nor did it increase nonspecific endocytosis by these cells, as shown by the failure to influence normal albumin uptake and degradation. In the absence of IFN- $\gamma$, the cachectin/TNF effect was uniformly reduced to $60 \%$ of that observed in the presence of this cytokine (data not shown).

Since AGE-protein uptake by human peripheral monocytes has been shown to induce secretion of cachectin/TNF (9), we reasoned that preincubation of monocytes with AGEBSA or FFI-BSA at concentrations known to induce this monokine ( 250 and $150 \mu \mathrm{g} / \mathrm{ml}$, respectively, in the presence of IFN- $\gamma$ ), should enhance AGE-BSA processing. As shown in Fig. $5 A$, monocytes preincubated with nonenzymatically glycosylated BSA formed either naturally by in vitro incubation with glucose (AGE-BSA) or by chemically attaching the synthetic AGE, FFI, to albumin (FFI-BSA), increased cellular accumulation of radiolabeled AGE-BSA approximately sixfold as compared with control untreated cells $(P<0.005)$. This amount of intracellular accumulation was comparable to the effect seen after the preincubation of the human monocytes with cachectin/TNF for the same period of time (Fig. $5 \mathrm{~A}$ ). The amounts of labeled AGE-BSA degraded during these experiments followed a similar pattern: AGE-BSA or FFI-BSA pretreatment enhanced degradation of AGE-ligand (Fig. $5 \mathrm{~B}$ ). In contrast, AGE-BSA or FFI-BSA treatment had no effect on the accumulation or degradation of unmodified radiolabeled BSA.

A more than twofold increase in the amount of radiolabeled AGE-protein specifically bound at $4^{\circ} \mathrm{C}$ by cells pretreated with cachectin/TNF, and FFI-BSA was also noted (Fig. 6), compared to untreated monocytes. Parallel experiments

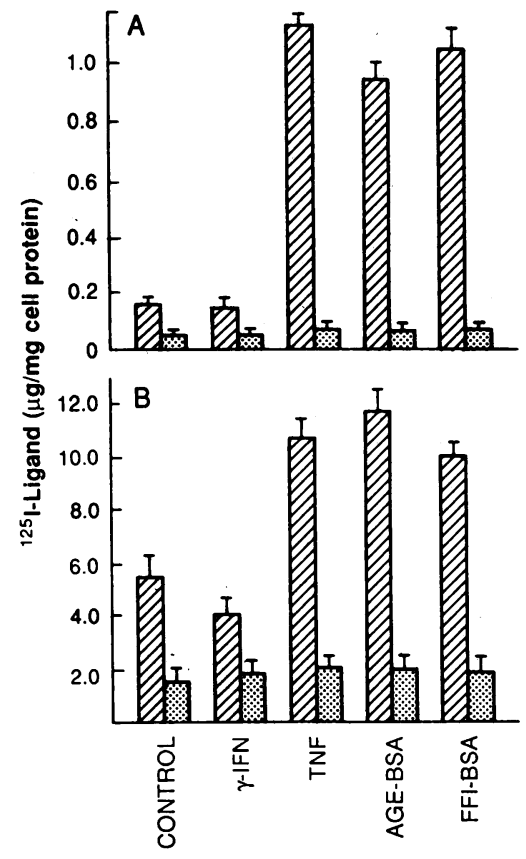

Figure 5. Intracellular accumulation $(A)$, and degradation $(B)$ of ${ }^{125} \mathrm{I}$ AGE-BSA (hatched bars) or ${ }^{25}$ I-BSA (dotted bars) by freshly isolated human peripheral blood monocytes, for $4 \mathrm{~h}$ at $37^{\circ} \mathrm{C}$. After preincubation with the indicated agents for $48 \mathrm{~h}$ at $37^{\circ} \mathrm{C}$ in the presence of IFN- $\gamma(1 \mathrm{ng} / \mathrm{ml}, 50$ $\mathrm{U} / \mathrm{ml}$ ), cells were washed three times and fresh media was replaced. Control wells contained cells preincubated in medium with serum alone, for the same period of time before receiving the appropriate radioactive ligand. Data are expressed as the means \pm SEM of duplicate values from six independent experiments. Amount of radioligand added to the medium was $25 \mu \mathrm{g} / \mathrm{ml}$. 


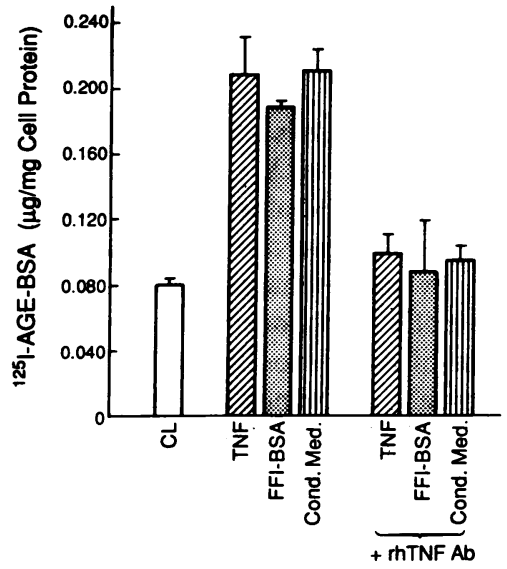

ing with fresh cold media, binding studies of labeled AGE-BSA were carried out for $2 \mathrm{~h}$ at $4^{\circ} \mathrm{C}$. Conditioned medium represents medium obtained from human monocytes treated previously with FFI-BSA, and IFN- $\gamma$ for $48 \mathrm{~h}$. Data are expressed as the means \pm SEM of duplicate values from three independent experiments.

using unmodified normal BSA in the preincubation medium produced no detectable changes in radiolabeled AGE-BSA binding, uptake, or degradation by normal monocytes (data not shown).

Table II. Dose/response Data for AGE-BSA and FFI-BSA Pretreatment of Human Monocytes of ${ }^{125} I-A G E-B S A(25 \mu \mathrm{g} / \mathrm{ml})$ Binding, after Either 2 or $5 d$ of Incubation followed by 48-h Preincubation with Each Stimulant*

\begin{tabular}{ccc}
\hline & \multicolumn{2}{c}{$\begin{array}{c}\text { 125I-AGE-BSA binding } \\
(\mu \mathrm{g} / \mathrm{ml} \text { cell protein })\end{array}$} \\
\cline { 2 - 3 } Pretreatment added: & Day 2 & \multicolumn{1}{c}{ Day $7^{\ddagger}$} \\
\hline$\mu g / m l$ & & \\
AGE-BSA & & \\
0 & $0.07 \pm 0.02$ & $0.18 \pm 0.02$ \\
10 & $0.06 \pm 0.02$ & $0.25 \pm 0.03$ \\
100 & $0.15 \pm 0.05^{\S}$ & $0.68 \pm 0.10^{\S}$ \\
250 & $0.25 \pm 0.09^{\prime \prime}$ & $0.94 \pm 0.16^{\prime \prime}$ \\
500 & $0.13 \pm 0.02$ & $0.25 \pm 0.05$ \\
FFI-BSA & & \\
0 & & \\
10 & $0.06 \pm 0.04$ & $0.20 \pm 0.03$ \\
50 & $0.05 \pm 0.03$ & $0.40 \pm 0.06$ \\
100 & $0.13 \pm 0.06^{\prime \prime}$ & $0.71 \pm 0.09$ \\
250 & $0.22 \pm 0.06^{\prime \prime}$ & $0.82 \pm 0.10^{\prime \prime}$ \\
& $0.12 \pm 0.04$ & $0.36 \pm 0.05$ \\
\hline
\end{tabular}

* AGE-BSA or FFI-BSA was added to cell cultures at the indicated concentrations for $48 \mathrm{~h}$. After washing stimulants away and replacing with cold media containing IFN- $\gamma(1 \mathrm{ng} / \mathrm{ml}, 50 \mathrm{U} / \mathrm{ml})$, binding studies of labeled AGE-BSA were performed as described (6). Data are expressed as means \pm SEM of duplicate values from three independent experiments.

${ }^{\ddagger}$ Stimulant (AGE-BSA or FFI-BSA) was added during the last $48 \mathrm{~h}$ in culture.

${ }^{\S} P$ value was $<0.05$ as compared to controls incubated in the $a b-$ sence of stimulant (24).

" $P$ value was $<0.005$ as compared to controls incubated in the absence of stimulant (24).
The range of effective concentrations of AGE-modified protein capable of upregulating AGE-receptor function on human monocytes were tested by preincubating the cells with various concentrations of AGE-BSA or FFI-BSA. As shown in Table II, AGE-receptor binding increased in response to increasing AGE-modified protein concentration up to $250 \mu \mathrm{g} / \mathrm{ml}$ for AGE-BSA, and $100 \mu \mathrm{g} / \mathrm{ml}$ for FFI-BSA, beyond which levels the response began to decline.

The results of the experiments described above indicated that cachectin/TNF was capable of upregulating AGE-receptor expression, possibly via a specific binding site on the macrophage/monocyte cell surface, therefore we tested for cachectin/TNF receptors on both cells. As shown in Fig. 7, both mouse peritoneal macrophages $(A)$, and human monocytes $(B)$ bound human cachectin/TNF with saturable kinetics. Scatchard plot analysis of binding data indicated that the mouse macrophage has $1.5 \times 10^{3}$ receptors/cell $\pm 48 \mathrm{SEM}$, with a dissociation constant $\left(K_{\mathrm{d}}\right)$ of $0.32 \mathrm{nM}$, while freshly isolated normal human monocytes possessed $1.6 \times 10^{3}$ binding sites/ cell $\pm 25 \mathrm{SEM}$ with a $K_{\mathrm{d}}$ of $0.48 \mathrm{nM}$.

To test the hypothesis that the AGE-mediated increase of AGE-receptor function is mediated by the released cachectin/ TNF (9), which in turn interacted with its own surface receptors in an autocrine fashion to exert an effect on the AGE-receptor, human monocytes were preincubated for $48 \mathrm{~h}$ with either cachectin/TNF, FFI-BSA, or conditioned medium (prepared from human monocytes previously exposed to FFI-BSA for $48 \mathrm{~h}$ ), in the presence and absence of an anticachectin/TNF
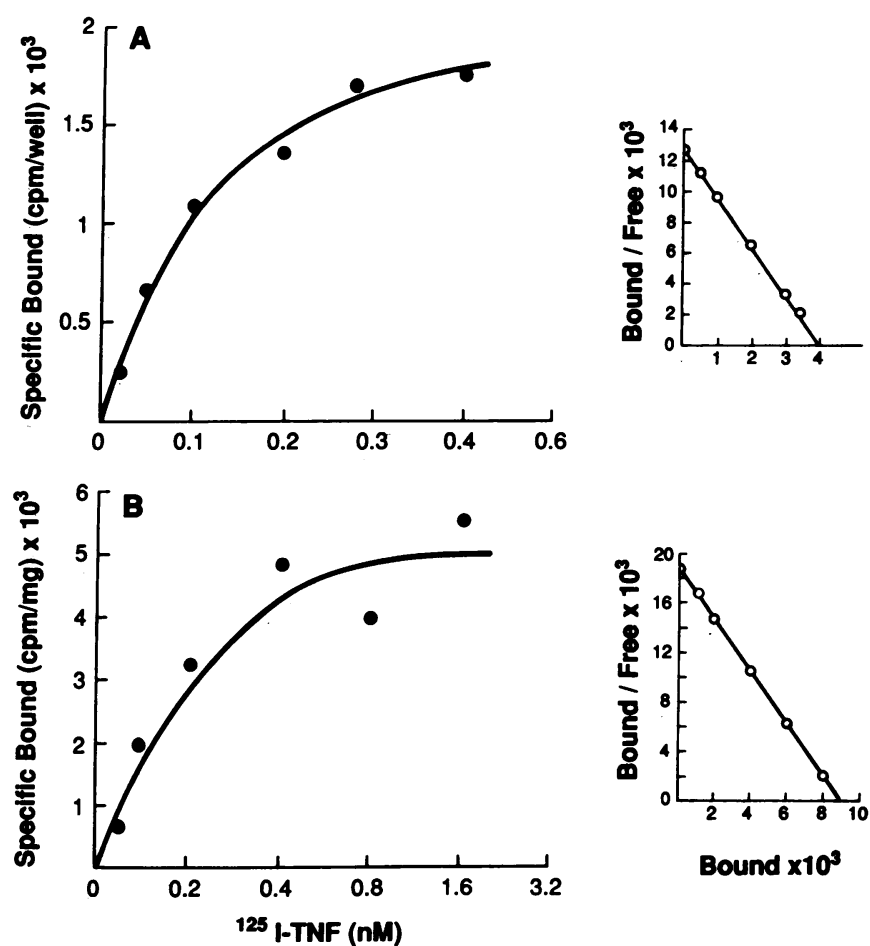

Figure 7. Specific binding of ${ }^{125}$ I-rhTNF by murine peritoneal macrophages $(A)$ and by human peripheral monocytes $(B)$, and Scatchard plot analysis (insets) of data, in the presence or absence of 1,000 -fold excess unlabeled rhTNF. Specific binding data were determined from triplicate values and are expressed as means \pm SEM of two independent experiments. Units for Scatchard analysis are: $(A)$ bound, $\mathrm{cpm}$ $\times 10^{3}$; bound/free, $\left(\mathrm{cpm} \cdot \mathrm{nM}^{-1}\right) \times 10^{3}$. (B) Bound $\left(\mathrm{cpm} \cdot \mathrm{mg}^{-1}\right)$ $\times 10^{3} ;$ bound $/$ free, $\left(\mathrm{cpm} \cdot \mathrm{mg}^{-1} \cdot \mathrm{nM}^{-1}\right) \times 10^{3}$. 
specific monoclonal antibody (SW 18.1.1) (22). This antibody has been shown to completely neutralize TNF biological activity, as measured by cachectin/TNF-mediated L929 cell cytotoxicity (22), without affecting TNF- $\beta$ (lymphotoxin) activity (unpublished data). The cells were then allowed to bind radiolabeled AGE-BSA for $2 \mathrm{~h}$ at $4^{\circ} \mathrm{C}$. As can be seen in Fig. 6, the presence of the monoclonal antibody inhibited the stimulatory effect of cachectin/TNF, FFI-BSA, or conditioned medium on ${ }^{125}$ I-AGE-BSA binding by $90 \%$. The prevention of AGE-receptor upregulation by the monoclonal antibody added to the conditioned medium indicated that cachectin/TNF was the predominant factor involved in this process.

In order to assess the ability of cachectin/TNF to induce similar upregulation of the AGE-receptor-mediated processes in vivo, we measured the in vivo survival of red blood cells that had been modified by linking FFI onto their surfaces. Previous work (8) had shown that in mice these modified $\mathrm{RBC}$ have a shortened survival in the circulation compared with normal RBC. Red blood cells from donor rats were modified by FFI$\mathrm{HA}$ or with PBS alone (8), and after ${ }^{51} \mathrm{Cr}$-labeling were injected intravenously into recipient animals which were given rhTNF intraperitoneally twice daily for $7 \mathrm{~d}$. Rats receiving cachectin/ TNF failed to gain body weight and displayed a $26 \%$ decline in hematocrit (data not shown), which is consistent with earlier reports (23). As shown in Fig. 8, the clearance rate of FFI-modified cells was markedly increased in rats injected with cachectin/TNF; the half-life of FFI-labeled RBCs was reduced to $<3$ $\mathrm{d}$ in cachectin/TNF $\alpha$-treated animals, significantly shorter than the half-life of $6 \mathrm{~d}$ observed with FFI-labeled RBCs in the animals that received saline alone.

\section{Discussion}

During the constant removal and resynthesis of cellular and tissue proteins, signals orchestrating an orderly remodeling are required. Macrophages and monocytes are important contributors to the regulation of extracellular matrix protein turnover (27). One mechanism that would allow these cells to selectively identify, internalize, and destroy senescent proteins is the high-affinity receptor specific for the AGE moiety (5-7). In recent studies we have begun to examine the process by which removal of AGE-modified proteins might be coordinated with their replacement by newly synthesized material. We have found that in response to binding AGE-proteins, human monocytes synthesize and release the monokines cachectin/ TNF and IL-1 (9). These proteins are known to have diverse

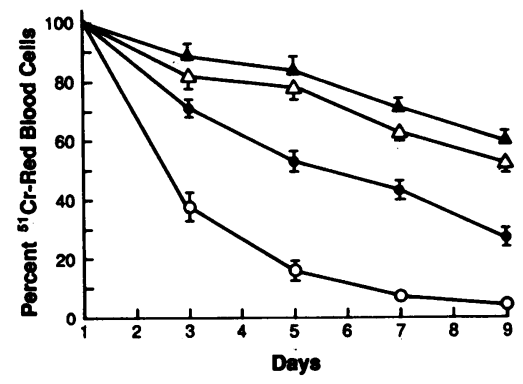

Figure 8. Survival of rat ${ }^{51}$ Cr-labeled FFI-RBCs $\left(8 \times 10^{5} \mathrm{cpm} / 200 \mu \mathrm{l} / \mathrm{rat}\right.$ i.v.), $(\bullet, 0)$ as a function of time (days), while receiving either recombinant cachectin/TNF ( $250 \mu \mathrm{g} / \mathrm{kg}$ twice daily) (o) or normal saline (๑), and survival of similarly labeled normal unmodified RBCs $\left(6.5 \times 10^{5}\right.$

$\mathrm{cpm} / 200 \mu \mathrm{l} / \mathrm{rat}$ i.v.) $(\Delta, \Delta)$ as a function of time (days), while receiving either recombinant cachectin/TNF $(250 \mu \mathrm{g} / \mathrm{kg}$ twice daily) $(\Delta)$ or normal saline $(\boldsymbol{\Lambda})$. biological effects (28) including growth factor-like (29-31) and angiogenic activities $(32,33)$ possibly involved in tissue growth and remodeling.

The effectiveness of this repair process is also dependent on the efficient removal of altered proteins. We have therefore examined the ability of physiological mediators such as insulin (12), and cachectin/TNF to regulate the rate of uptake and elimination of AGE-protein by macrophages. In this study cachectin/TNF induced a severalfold enhancement of binding, endocytosis and degradation of AGE-modified albumin by both murine resident peritoneal macrophages and human blood monocytes in vitro, and it enhanced the rate of disappearance of AGE-modified erythrocytes in vivo. In contrast, IL-1 did not stimulate the AGE-receptor specific activity, although it did induce endocytosis and processing of unmodified albumin by an apparently nonspecific mechanism. In addition, IFN- $\gamma$ did not upregulate the AGE-receptor activity on murine macrophages on its own, despite its known macrophage activating properties (25), and it did not influence the effects of human cachectin/TNF on murine macrophage AGE-receptors.

Circulating human monocytes were selected as the most accessible human macrophage equivalent to test the general clinical relevance of these observations. Nonstimulated human monocytes after either 2 or $7 \mathrm{~d}$ in culture have very similar numbers of AGE-specific binding sites to murine resident peritoneal macrophages (6); however, the affinity of the human monocyte AGE-receptor was shown to be 10-fold lower than its murine counterpart (6), which may reflect nonprimed macrophage precursor state. IFN- $\gamma$ was therefore used on human monocytes in an effort to more closely mimic primed tissue macrophages from mice $(34,35)$. Others $(36)$ have previously shown that IFN- $\gamma$ alone elicits no detectable secretion of cachectin/TNF, although it can increase TNF binding to various cell lines $(37,38)$. In addition, we have reported its ability to augment monocyte production of cachectin/TNF and IL-1 in response to AGE-protein (9). It was therefore included as an enhancement factor during our exploration of AGE-receptor expression of the human monocyte under the influence of cachectin/TNF. It is again noteworthy that IFN- $\gamma$ alone did not influence either the specific uptake of AGE-BSA or the nonspecific uptake of normal BSA, while it consistently augmented cellular AGE-receptor expression in response to cachectin/TNF.

After $7 \mathrm{~d}$ differentiation in culture, when blood monocytes are also considered to be more equivalent to tissue macrophages $(39,40)$, the amount of labeled AGE-BSA bound increased considerably over that found on freshly isolated cells. This confirms earlier studies on human monocytes in which it was observed that the binding of AGE-modified RBC was maximal after 1 wk of culture (8). Similar observations have been made with regard to the expression of other monocyte surface receptors, such as the Fc (41), and the scavenger receptor for modified LDL (42), reflecting the maturation of these cells into macrophages. However, the marked increases (fourto sixfold) in AGE-receptor expression observed after preincubation of 7-d-old monocytes with cachectin/TNF may reflect the greater in vivo potential of this macrophage receptor system at the tissue level.

Although cachectin/TNF receptors have been demonstrated on many cell types (43-45), they have not been shown to be present on macrophages or monocytes. Therefore, the 
identification of cachectin/TNF receptors on these cells was important for this study since a high-affinity binding site on the cell surface would explain the cachectin/TNF upregulation of the AGE-receptor function. The dissociation constant of radiolabeled cachectin/TNF for the macrophage/monocyte (300-500 pM) was similar to that of cachectin/TNF for other cells $(100-300 \mathrm{pM})(43,44)$, as was the number of binding sites $(\sim 1,500$ sites/cell) (45).

From the studies presented above it seems plausible that the macrophage utilizes cachectin/TNF, induced by AGEprotein uptake (9), in an autocrine manner to regulate the AGE-receptor function. TNF binds with a 1,000-fold higher affinity than AGE-BSA to the cells, therefore only a small amount bound to the TNF-receptor is necessary to influence AGE-receptor function. Similarly, other receptor functions have been shown to be modulated by hormones such as the downregulation of both Fc- (46) and AGE-receptor function (12) by insulin. Within $48 \mathrm{~h}$ of exposure to cachectin/TNF, macrophages undergo a modulation of their AGE-protein recognition capacity allowing them to promote the removal of AGE-proteins maximally. The specificity of cachectin/TNF action to induce increased AGE-receptor function is noted by its complete prevention by a monoclonal antibody that is specific for TNF- $\alpha$ and not TNF- $\beta$ (22, and unpublished data). Similarly the ability of this monoclonal antibody to inhibit the effect induced by conditioned media from macrophages previously incubated with AGE-ligands points to cachectin/TNF as the major mediator. This result is important since macrophages have the ability to produce a large number of mediators. The mechanism by which the monoclonal antibody neutralizes AGE-receptor upregulation has not yet been determined but, in view of the evidence for TNF receptors on these cells, one possibility is the inhibition of binding to the TNFreceptor; however other possibilities still exist.

Previous work has revealed that in vivo cachectin/TNF mimics many of the changes seen in chronic cachexia, including anemia (47). A recent study on the mechanism of this anemia induced by cachectin/TNF has indicated a decreased rate of new red cell production, but more interestingly, a shortening of the lifespan of circulating red cells (23). It is possible that this latter finding represents, in part, an upregulation of the AGE-receptor system resulting in an enhanced rate of removal specifically of those red cells with AGE-moieties formed on their surface proteins as a function of age in circulation. We have previously demonstrated a decreased in vivo survival of AGE-modified RBC (8), suggesting that these cells are selectively removed from the circulation. Our in vivo experiments of chronic cachectin/TNF administration causing acceleration of the disappearance rate of AGE-modified RBC in particular, support this notion.

AGE-protein uptake by macrophages leads to synthesis and release of cachectin/TNF and IL-1 (9). These mediators in turn, can prompt the release of additional mediators $(28,48)$, as well as proteolytic enzymes such as collagenase (49), which collectively may provide the additional signals required for local tissue remodeling. The AGE-receptor is the first receptor known to recognize a protein modification that forms extensively in vivo as a function of time and glucose concentration. Via this system macrophages can selectively promote the degradation of senescent macromolecules, and simultaneously initiate the process of tissue regeneration $(1,9)$.

The demonstration of the upregulation of the AGE-recep- tor by cachectin/TNF contributes to the emerging picture of a physiological mechanism in which the macrophage AGE-receptor via cytokine induction could play a central role in the modulation of tissue protein turnover. In addition, the cachectin/TNF interaction with the AGE-receptor through an autocrine pathway may allow adaptation of the system to local requirements so that tissue homeostasis can be maintained. This finely coordinated macrophage system, although of unknown as yet capacity for senescent molecules in vivo, appears to function efficiently for several decades under physiologic conditions. Under significant burden, however, such as with aging or diabetes, where excessive tissue AGE accumulation is observed, an altered AGE-receptor expression (12) may reflect in part an inability of the macrophages to respond to the stimulatory effect of cachectin/TNF.

\section{Acknowledgments}

We are grateful for the support of National Institutes of Health grants RO1-AM19655, RO1-AM33861, GM-40586-01, and RO1-AI15674 and of grants from the Juvenile Diabetes Foundation and the Brookdale Foundation.

\section{References}

1. Brownlee, M., A. Cerami, and H. Vlassara. 1988. Advanced glycosylation end products in tissue and the biochemical basis of diabetic complications. N. Engl. J. Med. 318:1315-1321.

2. Brownlee, M., H. Vlassara, and A. Cerami. 1984. Nonenzymatic glycosylation and the pathogenesis of diabetic complications. Ann. Intern. Med. 101:527-537.

3. Brownlee, M., H. Vlassara, and A. Cerami. 1987. The pathogenetic role of nonenzymatic glycosylation in diabetic complications. In Diabetic Complications: Scientific and Clinical Aspects. M. J. C. Crabbe, editor. Pitman, London. 94-139.

4. Monnier, V. M., R. R. Kohn, and A. Cerami. 1984. Accelerated age-related browning of human collagen in diabetes mellitus. Proc. Natl. Acad. Sci. USA. 81:583-587.

5. Vlassara, H., M. Brownlee, and A. Cerami. 1984. Accumulation of diabetic rat peripheral nerve myelin by macrophages increases with the presence of advanced glycosylation endproducts. J. Exp. Med. 160:197-207.

6. Vlassara, H., M. Brownlee, and A. Cerami. 1985. High-affinity receptor-mediated uptake and degradation of glucose-modified proteins: a potential mechanism for the removal of senescent macromolecules. Proc. Natl. Acad. Sci. USA. 82:5588-5592.

7. Radoff, S., H. Vlassara, and A. Cerami. 1988. Characterization of a solubilized cell surface binding protein on macrophages specific for proteins modified non-enzymatically by advanced glycosylation endproducts. Arch. Biochem. Biophys. 263:418-423.

8. Vlassara, H., J. Valinsky, M. Brownlee, C. Cerami, S. Nishimoto, and A. Cerami. 1987. Advanced glycosylation endproducts on erythrocyte cell surface induce receptor-mediated phagocytosis by macrophages: a model for turnover of aging cells. J. Exp. Med. 166:539-549.

9. Vlassara, H., M. Brownlee, K. R. Manogue, C. A. Dinarello, and A. Pasagian. 1988. Cachectin/TNF and IL-1 induced by glucose-modified proteins: role in normal tissue remodeling. Science (Wash. DC). 240:1546-1548.

10. Warren, M. K., and S. N. Vogel. 1985. Opposing effects of glucocorticoids on interferon-gamma-induced murine macrophage $\mathrm{Fc}$ receptor and Ia antigen expression. J. Immunol. 134:2462-2469.

11. Fox, P. L., and P. E. DiCorleto. 1986. Modified low density lipoproteins suppress production of a platelet-derived growth factor- 
like protein by cultured endothelial cells. Proc. Natl. Acad. Sci. USA. 83:4774-4778.

12. Vlassara, H., M. Brownlee, and A. Cerami. 1988. Specific macrophage receptor activity for advanced glycosylation end products inversely correlates with insulin levels in vivo. Diabetes. 37:456-461.

13. Gmelig-Meyling, F., and T. A. Waldmann. 1980. Separation of human blood monocytes and lymphocytes on a continuous Percoll gradient. J. Immunol. Methods. 33:1-9.

14. Wright, S. D., and S. C. Silverstein. 1982. Tumor-promoting phorbol esters stimulate $\mathrm{C} 3 \mathrm{~b}$ and $\mathrm{C} 3 \mathrm{~b}^{\prime}$ receptor-mediated phagocytosis in cultured human monocytes. J. Exp. Med. 156:1149-1164.

15. Bianco, C., A. Eden, and Z. A. Cohn. 1976. The induction of macrophage spreading: role of coagulation factors and the complement system. J. Exp. Med. 144:1531-1544.

16. Kohn, R. R., A. Cerami, and V. M. Monnier. 1984. Collagen aging in vitro by nonenzymatic glycosylation and browning. Diabetes. 33:57-59.

17. Chang, J. C. F., P. C. Ulrich, R. Bucala, and A. Cerami. 1985. Detection of an advanced glycosylation product bound to protein in situ. J. Biol. Chem. 260:7070-7074.

18. Pongor, S., P. C. Ulrich, F. A. Bencsath, and A. Cerami. 1984. Aging of proteins: isolation and identification of a fluorescent chromophore from the reaction of polypeptides with glucose. Proc. Natl. Acad. Sci. USA. 81:2684-2688.

19. Fraker, P. J., and J. C. Speck, Jr. 1978. Protein and cell membrane iodinations with a sparingly soluble chloroamide, 1,3,4,6-tetrachloro-3a,6a-diphenylglycouril. Biochem. Biophys. Res. Commun. 80:849-857.

20. Scatchard, G. 1949. The attractions of proteins for small molecules and ions. Ann. NY Acad. Sci. 51:660-672.

21. Bradford, M. 1976. A rapid and sensitive method for the quantitation of microgram quantities of protein utilizing the principle of protein-dye binding. Anal. Biochem. 72:248-254.

22. Romero, R., K. R. Manogue, M. D. Mitchell, Y. K. Wu, J. C. Hobbins, and A. Cerami. 1989. A novel role for cachectin/tumor necrosis factor: signal for the initiation of premature labor in women with intraamniotic infection. Am. J. Obstet. Gynecol. 161:336-341.

23. Moldawer, L. L., M. Marano, H. Wei, Y. Fong, M. L. Silen, G. Kuo, K. R. Manogue, H. Vlassara, H. Cohen, A. Cerami, and S. F. Lowry. 1989. Cachectin/tumor necrosis factor-alpha alters red blood cell kinetics in vivo and induces anemia. FASEB (Fed. Am. Soc. Exp. Biol.) J. 3:1637-1642.

24. Zar, J. 1974. Biostatistical Analysis. Prentice-Hall, Englewood Cliffs, NJ. 241.

25. Nathan, C. F., H. W. Murray, M. W. Wiebe, and B. Y. Rubin. 1983. Identification of interferon-gamma as the lymphokine that activates human macrophage oxidative metabolism and antimicrobial activity. J. Exp. Med. 158:670-689.

26. Pace, J. L., S. W. Russell, R. D. Schreiber, A. Altman, and D. H. Katz. 1983. Macrophage activation: priming activity from a T-cell hybridoma is attributable to interferon-gamma. Proc. Natl. Acad. Sci. USA. 80:3782-3786.

27. Krane, S. M. 1984. Collagen degradation. In Progress in Clinical and Biological Research. Vol. 154. P. D. Berk, H. Castro-Malaspina, and L. R. Wasserman, editors. Alan R. Liss, New York. 89-102.

28. Sherry, B., and A. Cerami. 1988. Cachectin/tumor necrosis factor exerts endocrine, paracrine, and autocrine control of inflammatory responses. J. Cell Biol. 107:1269-1277.

29. Sugarman, B. J., B. B. Aggarwal, P. E. Hass, I. S. Figari, M. A. Palladino, Jr., and H. M. Shepard. 1985. Recombinant human tumor necrosis factor-alpha: effects on proliferation of normal and transformed cells in vitro. Science (Wash. DC). 230:943-945.

30. Nawroth, P. P., and D. M. Stern. 1986. Modulation of endothelial cell hemostatic properties by tumor necrosis factor. J. Exp. Med. 163:740-745.

31. Gajdusek, C., S. Carbon, R. Ross, P. P. Nawroth, and D. Stern.
1986. Activation of coagulation releases endothelial cell mitogens. $J$. Cell Biol. 103:419-428.

32. Leibovich, S. J., P. J. Polverini, H. M. Shepard, D. M. Wiseman, V. Shively, and N. Nuseir. 1987. Macrophage-induced angiogenesis is mediated by tumour necrosis factor-alpha. Nature (Lond.). 329:630-632.

33. Frater-Schroder, M., W. Risau, R. Hallmann, P. Gautschi, and P. Bohlen. 1987. Tumor necrosis factor type alpha, a potent inhibitor of endothelial cell growth in vitro, is angiogenic in vivo. Proc. Natl. Acad. Sci. USA. 84:5277-5281.

34. Nedwin, G. E., L. P. Svedersky, T. S. Bringman, M. A. Palladino, Jr., and D. V. Goeddel. 1985. Effect of interleukin 2, interferongamma, and mitogens on the production of tumor necrosis factor alpha and beta. J. Immunol. 135:2492-2497.

35. Nathan, C. F., T. J. Prendergast, M. E. Wiebe, E. R. Stanley, E. Platzer, H. G. Remold, K. Welte, B. Y. Rubin, and H. W. Murray. 1984. Activation of human macrophages: comparison of other cytokines with interferon-gamma. J. Exp. Med. 160:600-605.

36. Beutler, B., V. Tkacenko, I. Milsark, N. Krochin, and A. Cerami. 1986. Effect of gamma interferon on cachectin expression by mononuclear phagocytes. Reversal of the lpsd (endotoxin resistance) phenotype. J. Exp. Med. 164:1791-1796.

37. Aggarwal, B. B., T. E. Essalu, and P. E. Hass. 1985. Characterization of receptors for human tumour necrosis factor and their regulation by $\gamma$-interferon. Nature (Lond.). 318:665-667.

38. Israel, S., T. Hahn, H. Holtmann, and D. Wallach. 1986. Binding of human TNF- $\alpha$ to high-affinity cell surface receptors: effect of IFN. Immunol. Lett. 12:217-224.

39. Cohn, Z. A., and B. Benson. 1964. The differentiation of mononuclear phagocytes: morphology, cytochemistry, and biochemistry. $J$. Exp. Med. 121:153-170.

40. Johnson, W. B., B. Mei, and Z. A. Cohn. 1977. The separation, long-term cultivation, and maturation of the human monocyte. $J$. Exp. Med. 146:1613-1626.

41. Bianco, C., and B. Pytowski. 1981. Fc and C3 receptors. In Methods for Studying Mononuclear Phagocytes. D. Adams, P. Edelson, and H. Koren, editors. Academic Press, Inc., New York. 273-282.

42. Haberland, M. E., R. R. Rasmussen, C. L. Olch, and A. M. Fogelman. 1986. Two distinct receptors account for recognition of maleyl-albumin in human monocytes during differentiation in vitro. $J$. Clin. Invest. 77:681-689.

43. Baglioni, C., S. McCandless, J. Tauernier, and W. Fiers. 1985. Binding of human tumor necrosis factor to high affinity receptors on HeLa and lymphoblastoid cells sensitive to growth inhibition. J. Biol. Chem. 260:13395-13397.

44. Rubin, B. Y., S. L. Anderson, S. A. Sullivan, B. D. Williamson, E. A. Carswell, and L. J. Old. 1985. High affinity binding of 125I-labeled human tumor necrosis factor (LUKII) to specific cell surface receptors. J. Exp. Med. 162:1099-1104.

45. Beutler, B., J. Mahoney, N. Le Trang, P. Pekala, and A. Cerami. 1985. Purification of cachectin, a lipoprotein lipase-suppressing hormone secreted by endotoxin-induced RAW 264.7 cells. J. Exp. Med. 161:984-995.

46. Abrass, C. K., and M. Hori. 1984. Alterations in Fc receptor function of macrophages from streptozotocin-induced diabetic rats. $J$. Immunol. 133:1307-1312.

47. Tracey, K. J., H. Wei, K. R. Manogue, Y. Fong, D. G. Hesse, H. T. Nguyen, B. Beutler, R. S. Cotran, A. Cerami, and S. F. Lowry. 1988. Cachectin/TNF induces cachexia, anemia, and inflammation. $J$. Exp. Med. 167:1211-1227.

48. Le, J., D. Weinstein, U. Gubler, and J. Vilcek. 1987. Induction of membrane-associated interleukin 1 by tumor necrosis factor in human fibroblasts. J. Immunol. 138:2137-2142.

49. Brenner, D. A., M. O'Hara, P. Angel, M. Chojkier, and M. Karin. 1989. Prolonged activation of jun and collagenase genes by tumour necrosis factor- $\alpha$. Nature (Lond.). 337:661-663. 